\title{
A Study to Determine Consumers' Attitudes, Expectations and Perceptions for Halal Certified Products: Isparta Province as an Example
}

\author{
Ferdi Akbiyik $^{1} \&$ A. Hüsrev Eroğlu ${ }^{2}$ \\ ${ }^{1}$ Faculty of Economics and Administration Sciences, Department of Business Administration, Süleyman Demirel \\ University, Isparta, Turkey. \\ ${ }^{2}$ Faculty of Economics and Administration Sciences, Department of Business Administration, Süleyman Demirel \\ University, Isparta, Turkey. \\ Correspondence: Ferdi Akbiyik, Faculty of Economics and Administration Sciences, Department of Business \\ Administration, Süleyman Demirel University, Isparta, Turkey.
}

Received: February 16, 2016

Accepted: March 3, 2016

Available online: March 9, 2016

doi:10.11114/ijsss.v4i4.1382

URL: http://dx.doi.org/10.11114/ijsss.v4i4.1382

\begin{abstract}
The main objective of this research is to measure and determine whether perceptions, attitudes and expectations of consumers towards Halal certified products differ according to their socio-demographic characteristics. The research is therefore quite critical in terms of donating ideas on the perceptions of Muslim consumers towards Halal certified products. The research tries to identify factors that may contribute to Halal branding or halal certification by using factor analysis. The findings of the research show that there are 6 factors that can promote to Halal certified product awareness which are promotion, place, attractiveness and quality, halal certification, price and market demand respectively.
\end{abstract}

Keywords: Halal Certified Product, Muslim Consumers, Factor Analysis

\section{Introduction}

Consumers can be under the influence of a number of factors when buying. Particularly, if the product they buy is a food one, they are then more sensitive and more critical. Consumers are no longer just interested in the food products they consume; but rather, they would like to examine and learn the preparation of the products and the additives the foods contain. In this context, there are some characteristics that the products should have so as to be bought especially by Muslim consumers. That the foods must be halal for some Muslim consumers comes first without any doubt. That is to say, halal is indispensable for the Muslim consumers' living standards. In particular, a man/woman acknowledging that he/she is a Muslim wishes to know the resources of foods and drinks, their production methods and which additives they consist of. Namely, the piety is effective in high level in the process of not purchasing any pork product (Özdemir and Yayl1, 2014: 185).

\subsection{Conception of 'Halal Product'}

Halal, which is an Arabic origin word and defined by IFANCA (Islamic Food and Nutrition Council of America) as 'legal; allowed' (Kurtoğlu ve Çiçek, 2013: 182) ${ }^{1}$ means; corresponding to religious rules, not being forbidden by religion, antonym of haram (http://www.tdk.gov.tr/); a thing which doesn't contain anything inconvenient for Muslims to consume (Zakaria, 2008: 604); allowed by Koran, lawful (Dali, vd, 2008: 3); permissible, hygienic or healthy (Shafie ve Othman,2006: 1).

It has become more important for consumers to purchase Halal foods as the competition between companies is getting more severe in a globalizing world and individual differences and personal expectations and needs become more diversified. Religious beliefs as a part of cultural element can also be added to these factors, which have an impact on consumers' buying. At this point, consumption of halal foods according to religious laws is of vital importance. However, for Muslim consumers not only a good quality of products, but also halal products are required (Golnaz vd.,

\footnotetext{
${ }^{1}$ For more information on this point: History of Religion, Volume 17, pages 173-175, Kürşat Demirci; Fiqh, 1998, Volume 17, pages $175-178$, Ferhat Koca
} 
2009: 65). In this respect, especially religionist Muslim consumers are very sensitive. Moreover, in the first time the humankind was tested by food in Paradise, after he had been created. ${ }^{2}$ Koran points out that Adam and his wife Eve who were settled in Paradise, were warned (Çakır, 2013: 22). "And We said, O Adam, dwell, you and your wife, in Paradise and eat therefrom in [ease and] abundance from wherever you will. But do not approach this tree, lest you be among the wrongdoers." (Surah Al-Baqarah 2/35). First of all, Allah told us to stay away from the haram (antonym of halal) foods which are forbidden for humankind to eat. Allah denounced the halal and haram products (foods) in the Koran. As in every case there are notifications in the Koran, too, why a food is not halal. Beyond the reasons for why some foods are haram, there are many hidden causes, benefits and advantages for humankind. In other words, although the sacred and the profane are an important test for the servant of God, HE did not forbid some foods due to a number of such reasons as granting toils to HIS servants, depriving them from HIS blessings, punishing them or ascribing divinity to some foods as well; but rather, HE supervised HIS servants' worldly and otherworldly interests in the provisions relating to food as in all the provisions HE laid down. In this context, the reasons for a food's being unlawful can be summarized as follows; the idea of monotheism and not compliance to the religious politics, being harmful to both body and soul, being malignant, being filthy / unclean, being predatory, the absence of sharia (Çayıroğlu, 2014: 69-94).

In the studies conducted on consumer behavior, it has appeared that the religious belief of consumers is associated with the consumption behavior of consumers (Swimbergh et al., 2009: 340). When the concept of halal product is mentioned, "products which are not prohibited by the religion and manufactured in accordance with the rules of the religion" come to mind (Torlak, 2012: 2). The concept that appears in the minds of consumers is mostly halal food and when the halal food is mentioned, meat and meat products come to mind. The following verses about the meat is quite illustrative in Holy Quran: Prohibited to you are dead animals, blood, the flesh of swine, and that which has been dedicated to other than Allah, and [those animals] killed by strangling or by a violent blow or by a head-long fall or by the goring of horns, and those from which a wild animal has eaten, except what you [are able to] slaughter [before its death], and those which are sacrificed on stone altars, and [prohibited is] that you seek decision through divining arrows. That is grave disobedience. ${ }^{3}$ (Surah Al-Mā'idah 5/3). In another verse; HE has only forbidden you what dies of itself and blood and flesh of swine and that over which any other name than that of Allah has been invoked (Surah An-Nahl 16/115). ${ }^{4}$ However, the concept of halal product is not just about meat and meat products. In this context, it should be kept in mind that the baked goods should also be lawful. Moreover, foods shall be composed of products which do not include any alcohol and alcohol derivatives alongside pork and pork products.

In Islam, the God has declared all things that are forbidden for HIS servants. In other words, Islam has set certain criteria to determine whether a food product is halal (Dali, et al., Ibid, 4). These are:

1. All the used foods and materials in food production must be halal.

2. Cattles and goats which are regarded as halal must be cut in accordance with Islam; and the cutting should be carried out by a Muslim who does not have any mental problem, with a sharp knife without being cruel to animals slaughtered.

3. The halal food should not be mixed with those suspected ones concerning their not being halal, and they should be kept away from the unlawful products of dog and pig during storage, handling, cooking and service.

\section{Halal Logo in Products}

Another issue that is important for consumers on the food products is "halal logo". Namely, halal food not only means the cutting of an animal in accordance with the principles and orders of a religion, and foods which are composed of beverages and foods not containing any alcohol, it is also the standard imposed on food and food processing process. In addition, halal food is regarded as more reliable, more healthful and has better quality. In this context, halal food is a concept that needs to be addressed in the light of scientific values.

The usage of halal logo has become an important criterion in the phase of evaluating the reliability and quality of food for both Muslim and non-Muslim consumers. As in the example, halal food requirements encompass such many traditional food quality standards as ISO9000, Quality and Healthy Practices (GHP), Good Manufacturing Practice (GMP), veterinary examination, the Codex Food Hazard Analysis and Critical Control Points (HACCP). In this context, the sectors that provide and apply halal food requirements produce more quality products when compared with the

\footnotetext{
2 Here, the "apple" is seen as a symbolic meaning for some religious scholars and it is thus important to illustrate the concept of halal. For further information: Encyclopaedia of Islam Religious Foundation of Turkey, Volume 16, Pages: 542-545.

${ }^{3}$ Fisk is defined as violating the ban and religious orders of Islam religion. To see more, Fiqh, 1996, Volume 13, pages 37-38, Ali Şafak; Hadith, 1996, Volume 13, pages 38-39, Emin Aşıkkutlu

${ }^{4}$ It is forbidden to eat dog, pig and any dead animal which is not cut according to the Islamic rules. To see more, Abdurrahman Jazeera, the Islamic Fiqh by Four Sects, translated by Mehmet Keskin, Cagr1 yayinlari, Istanbul, 1989, 49, 5/3
} 
sectors enabling and performing only food standarts (Teng et al., 2013: 90). Halal products may become more popular for non-Muslims, besides when the community realizes that halal products are healthier, more quality, environmentally friendly and they may increase the social welfare in the society, the consumption of all these products can go up among aforesaid consumers.

According to the report issued by Canadian Agriculture Food and Commercial Services in 2008, there is serious demand for products with halal logo among both Muslim and non-Muslim consumers and this is seen in countries which are both Muslim and non-Muslim ones. Similarly, non-Muslim Russians can show a tendency to shop in stores and shops run by Muslims. Because the Russians believe these products are fresher, more reliable and contain less bacteria and germs inside. Furthermore, they esteem that Muslims are very closely connected to their religion in which "deception or inducement" is strictly forbidden, and they thus rely on any product they receive from vendors in the Muslim consequences. Accordingly, the non-Muslim consumers in Philippines tend to prefer products with halal logo as they consider them to be healthier. That's to say, Filipino consumers think the product with halal logo is reliable and can therefore be consumed. A study conducted in Malaysia whose population is 24 percent of the Chinese population, 8 percent of Indian, has shown interesting results. Chinese and Indian consumers do not pay attention to whether they buy products lawful according to the religion. However, they can tend to consume products with halal logo as they consider the advantages (healthy, clean) provided by the consumption of them. Because they know the products with halal logo are subject to serious investigation (Golnaz, et al., 2010: 667-674).

Similarly, in another study carried out in Malaysia has shown that consumers have more confidence in the products with halal logo, and thus they purchase these ones. This sensitivity shown by consumers has been instrumental in the emergence of halal logo. Namely, Malaysian Islamic Development Department (JAKIM), was established on 1 January 1997 by the Malaysian government (www.islam.gov.tr). While Malaysian consumers pay so much confidence on this unit's halal logo, they do not esteem halal logo as much issued by different units (Golnaz, et al., 2012: 33-42). Yet another study conducted in Malaysia has revealed interesting results regarding products with halal logo, the perception of these products by consumers and their awarenesses. In other words, while 94 percent of the consumers participating in the study have an idea concerning the products with halal logo, only 6 percent of the consumers buy these products continuously. In addition, those who do not control the halal logo imposed on the products they buy are 45.9 percent (Teng et al., ibid, 97-98). One of the reasons that the consumers do not control the halal logo is that they live in a Muslim country, and thus they accept all the products (foods) which are produced and sold in that country as halal unless otherwise stated by the competent and relevant authorities (Dali et al., ibid, 5-6). Similarly, Muslim consumers assume that food products they buy are halal when they buy them from Muslim sellers, especially when the sellers wear headscarf or hat, which are mostly worn by Muslims (Zakaria ,. ibid, 608-609). In short, consumers would avoid the responsibility if the products they buy bore halal logo.

\section{Halal Product Certificate and Its Justification}

Another thing that consumers consider when buying food products is halal certificate. Especially, the importance of halal certification is increasing significantly in food products world trade. With the increasing awareness of consumers belonging to the Islamic religion, those products having halal certification are gaining advantages over non-halal food products in the world market (www.gmka.org.tr). Halal certification is an important and necessary application to produce acceptable and consumable products for Muslim consumers. Then, this case includes millions of people who prefer halal products in addition to 1.6 billion Muslim consumers.

The main organizations providing halal certificates in Turkey are GIMDES, TSE, World Halal Union, HELALDER and HEDEM (www.helalplatform.com). There are four main premises in the insurance of halal certificate. These are Islamic conditions, legal requirements (health suitability), documentation and control (www.etikadanismanlik.com).

While halal certification is extremely important for consumers looking for halal products, it has unfortunately been a new source of income for frauds, as halal product market is growing rapidly and it is claimed to be $\$ 2$ trillion. That is to say, halal certificate can be given very quickly at a price ranging from 5000 to 10.000 dollars and those certificates given by so-called bagmen may not be controlled due to legal loopholes (Sabah Newspaper-Economy, December 9, 2011).

Another problematic issue regarding Halal Certification is that these certificates are increasingly entering into the capitalist system. With the help of these certificates conferred with commercial concern and for marketing purpose, consumers are expected to raise awareness regarding halal and qualified products. When buying goods, consumers buy indeed a product bearing a symbol. This condition allowed symbols and indices to affect consumers; and they caused consumers to focus on icons and symbols the products carry rather than the substances they contain (Ameur, 2011: 88-89).

Lastly, that the those organizations or companies whose centers are not in Islamic countries give halal certificate and 
those, who are non-muslims in particular, only donate certificates as a specialist organization would not be very reliable and accurate. Besides, those organizations or institutions which will provide the halal certificate shall not be engaged in any food manufacturing plant or food product companies by themselves nor by their relatives (Batu, 2012: 53). Halal certification process must be extremely sensitive and no halal certificate shall be granted to the agencies and organizations unless necessary checks are carried out.

\section{Halal Certification}

Halal certification shows whether a product is halal. This document is a certificate given to the companies wishing to sell halal products, by institutions with required permits, equipment and experience.

\subsection{Halal Certification in the World}

In many parts of the world, several Islamic institutions, associations or foundations prepared various specifications in order to be sure what they eat and drink. The Islamic Society of North America, which is one of them, is a non-governmental organization which was founded in 1963 as a result of individual efforts of Muslims living in Canada. The work of these institutions started to bear fruit. Firstly, American and Canadian Muslims documented halal standards and they moved on to make new studies on halal subject. They also have signed up many studies on this subject so far. Another organization regarding this subject is IFANCA in the USA. IFANCA, founded in 1982, has been working about halal products ever since. One of the services provided to consumers by IFANCA is that it enables third-part certification as well. (Batu, ibid, 57-58).

\subsection{Halal Certification in Turkey}

In Turkey, researches related Halal certificate, though it could be seen beforehand slightly, emerged a little more markedly in the 1970s. Specifically, they started with the non-consumption of margarine and supported buying meat from religious butchers. Muslims became more cautious by not eating meat dishes in every restaurant. They also paid great attention even when buying toothbrushes due to their possibility of having bristle. In 1990s and in the early 2000s, halal-haram food lists and their E codes began to be published in different websites. Association and foundation work began to be created on this issue in the mid-2000s. Thus, non-governmental organizations were established to create halal food production and certification. With the idea that it would not be enough, the same group of volunteers founded GIMDES, whose main aim is to search for halal and healthy food for Muslim consumers and provide halal certificate for those products as an assurance for both market and consumers. GIMDES has been carrying out studies on this subject since 2005. At first, it worked various publications with the aim of formation of consciousness about this delicate topic. After it had been accredited by national and international organizations in 2009, it started giving halal certifications. In addition, The Turkish Standards Institute (TSE) has also a study in this regard. Halal food gained a public identity in Turkey through TSE in 4 July, 2011(Batu, ibid, 58-59).

In the examination carried out by at least two experts from Religious Affairs Directorate and TSE, plant examination reports, entry checklist, halal food certification sheet for the product groups, the checklist for slaughter, testing requirements are used. In the halal food examination, competences related to general examination and testing, the necessary conditions for the production site and certification procedures are sought. These include:

1- The examination and information regarding the test for the certification,

2- Manufacturing site examination requirements,

1. Conditions for the production facility,

2. Requirements related to the production equipment,

3. Requirements regarding food safety management system,

4. The requirements for quality control in personnel, examination and testing equipment (routine examination and testing),

5. The essentials concerning interlude controls,

3-Certification details of the procedure,

1. Inspection reports and inspection / test report (if any) shall prevail.

2. Additional issues related to Halal requirements are considered when necessary.

3. The following information should be in the scope of the document;

- The number of standard and effective date (TS OIC / SMIIC 1: July 2011)

- When Halal Brand is allowed to be used; 
o Product Group (Cereal and Cereal Products)

o Product name (Example: Cake)

In the preparation of documents used in the review, SMIIC Standards, ISO 22000 Food Safety Management System standards, Turkey legislation and Turkish Standards are taken into consideration. (Gündüz, 2013: 399-400).

\section{Food Additives in Halal Products}

Nowadays, food additives are classified as preservatives; substances that protect and develop structural properties of foods; colorants and aroma developers; sweeteners; flavor-boosting ones; those which protect and refine the nutritional value of food. Again, these additives are classified as A, B and C lists with the toxicological studies by organizations such as CAC and JECFA. Those additives, which are recognized reliable when followed all the rules which are put forward by ADI and NOAEL, make up a list. Additives about whose studies and reviews are yet unfinished are listed in the list $\mathrm{B}$. The $\mathrm{C}$ list includes those additives which are harmful to be used. If lard and blood, which are considered forbidden by religion, are used when preparing those additives and then if those additives are added to the halal products, all the halal products which were permitted until those additives were added themselves, shall unfortunately be forbidden ones. Similarly, if foods are cooked with additives that are prepared by using alcohol, they shall be forbidden once again, for alcohol is also recognized as forbidden by Islam religion. (Çayıroğlu, ibid, 321-387).

The use of food additives is extremely important. Because the additives which are added to foods may jeopardize their being halal. Therefore, there are some issues to be considered in the use of food additives. These are: (Yurttagül ve Ayaz, 2008: 8)

1- They should not be harmful to human health and they should be determined by the law as well.

2- Technological requirements should be included in use.

3- They should be used in permitted foods and in permitted amounts.

4- They should not reduce the nutritional value of food.

5- Food additives must be used not to overshadow the bad quality but to protect the quality.

\section{Halal Food Market}

"Halal Food Market" is rising rapidly in the world market. The actors of this market are Indonesia, Malaysia, the United States and the Gulf Arab countries. The present value of Halal food market is estimated as 850 billion US dollars, while all halal market is estimated to be around 2 trillion US dollars. Only 10 percent of this market seems to be realized. Especially that the market value of KOSHER, which is the halal certificate of the Jewish community whose population is 15 million people, is $\$ 250$ billion describes how important this market through the world (www.gimdes.org).

Halal marketing has become increasingly important, especially in European countries. For instance, halal product market in France has increased between 10 and 20 times since the early 1990s (Bergeaud-Blackler and Bonn, 2005: 3).

The demand for Halal food is increasing all over the world, yet especially in Middle East, Southeast Asia, North Africa, America, Europe, Canada, and Australia. Halal product market is one of the fastest growing markets in the world. There are 1.6 billion Muslim consumers who constitute 23 percent of the world population. 60 percent of them live in Asia, 20 percent of them live in the Middle East and North Africa. In addition, 300 million Muslims live in minority status in several countries. There are 38 million Muslims in Europe, 8 million Muslims in the USA, and about 1 million Muslims in Canada (www.gmka.org.tr). In this context, the global halal food market is already $\$ 600$ billion and is expected to grow at an annual rate of 20-30 percent (Soesilowat of 2010: 151).

As for Turkey, halal food market is expected to rise to 237 billion dollars in 2018. According to the statement of DinarStandard, the reason for this is that Islamic economy, especially halal food / lifestyle sectors (fashion, tourism, pharmaceutical, cosmetics and media / entertainment) have begun to develop globally (www.hurriyet.com.tr).

Some of those countries involving in the halal market by forming Halal certification standards or giving halal certification are as follows: the USA, the UK, Switzerland, Canada, South Africa, Australia, Malaysia, Indonesia, Thailand, Singapore, China, the Philippines, India and Turkey (www.gmka.org.tr).

Dr Hüseyin Kâmi Büyüközer, president of GIMDES, said that the largest share of halal certified product exports is shared among such countries as Brazil, China, Australia and Europe no matter how high is the number of countries giving halal certificate (www.dunyagida.com.tr). 


\section{A Study to Determine Consumers' Attitudes and Expectations for Halal Certified Products and Their Perceptions of Halal Certified Products, Isparta Province as an Example}

\subsection{Purpose and Scope of the Study}

Halal product is no longer just a religious concept, for it has already begun to be accepted as a commercial concept. In addition, halal product market is increasingly and rapidly growing. In order to get greater shares of this rapidly growing market, businesses thus need to understand the perceptions, attitudes and expectations of consumers regarding the halal products. Should the businesses realize how significant to comprehend the desires and anticipations of consumers to make them buy halal products, they do nothing but give their best to satisfy the consumers. The estimated market volume of halal products is 850 billion US dollars, and it can be 2 trillion dollars in total Halal Market. However, only 10 percent of this market seems to have taken place. Namely, halal products and services cover a wide spectrum of products and service lines ranging from personal hygiene products to the food. And in this humble study, emphasis will be given mainly to the food industry because when discussing about Halal, this food industry shall generally be the first to be paid attentioned and thus analyzed

The aim of this study is to define consumers' perceptions of halal products, attitudes, and expectations and to identify whether the consumers' perception of halal products, attitudes, and expectations differentiate according to their socio-demographic characteristics. Within this study, the perceptions, attitudes and expectations of consumers living in the central province of Isparta were investigated. The study was conducted on consumers living in the central province of Isparta due to time and financial constraints. In other words, this study covers only local people living in the city center of this province who were available to make contact with whom a contact was possible to make. Therefore, it is not possible to generalize the results of the study among all consumers and across the country.

\subsection{The Importance of the Study}

Today, about one-fourth of the world population consists of Muslims, which means a huge market for those looking for ways to sell halal products all in all. This figure is expected to rise up to 30 percent by the year 2025 by population experts. That the Muslims act under the influence of their religious beliefs when purchasing something makes halal product market increasingly important. Besides, because non-Muslims opt for halal products as they think that halal products are more hygienic and reliable, this halal market can grow more. Namely, for some consumers, though they are not Muslims, to consume a halal product especially if it is a halal food is quite significant in that halal products/foods are healthy and the consumer needn't be Muslims to buy and consume halal products.

This study will hopefully give a rise for the further academic studies as there are not enough studies concerning this delicate topic. Besides, with help of this study, the perceptions, attitudes and expectations of consumers will tried to be understood in order that businesses may set clear-cut targets so as to get a share of this huge and growing pie. Because halal market is a new yet non-ignorable market for those businesses seeking to expand their borders and looking for ways to earn more.

\subsection{The Model of the Study}

The sample of this study includes people living in the city center of Isparta province. The participants of this study were chosen randomly and the questionnaire study was conducted by using convenience sampling method.

Descriptive research model was used in this study. Besides, factor analysis, reliability test, T-test, anova and KMO tests were conducted in the study. According to the research model; perceptions, attitudes and expectations of the consumers, who are within the scope of this study, will be measured and will be tested whether all these perceptions, attitudes and expectations differ according to socio-demographic characteristics of consumers.

\subsection{Data Collection Tools}

A multiple-choice form consisting of three parts was used in the questionnaire study. The study reached to 476 participants. 47 question forms were not evaluated because of various reasons. The evaluation was performed (conducted) on the other 429 question forms. Following the entry of data to SPSS 15,0 statistical packet software, descriptive analysis and hypothesis tests were made. In the first part of the questionnaire, questions were asked to determine the socio-demographic characteristics of consumers. In the second part of the questionnaire, general questions were asked to determine the consumers' attitudes on halal products. In the last part of the questionnaire, consumers were asked to evaluate the products with halal logo. Overall, a questionnaire form was tried to be generated using the data obtained in the light of literature search. ${ }^{5}$ This scale was adapted for Turkish consumers. Afterwards, a pilot study was practiced on 40 people with these questions and some corrections were made in the latest version of the

\footnotetext{
5 Dali et.al. 2008 "Is Halal products are more expensive as perceived by the consumers? Muslimprenuers challenges and opportunities in establishing a blue ocean playin field" (1-22).
} 
questionnaire form. After a short statement on the subject, questionnaires were distributed to the consumers and then they were collected after having been filled out by them.

\subsection{Tested Hypothesis in the Study}

Socio-demographic variables are usually among the potential factors affecting consumer attitudes and expectations. It is therefore not surprising that these variables are used and tried to be measured in many studies. In this regard, the hypothesis of this study is "Consumers' perceptions of halal products, attitudes and expectations differ according to their demographic characteristics."

7.6 Analysis of the Study

Table 1. Demographic Findings Related to Consumers Participating in the Survey

\begin{tabular}{ccclcc}
\hline \multicolumn{1}{c}{ Age } & Frequency & Percent & Education Level & Frequency & Percent \\
\hline $18-27$ & 195 & 41,8 & Primary education & 41 & 9,2 \\
$28-35$ & 112 & 24,0 & High school & 66 & 14,7 \\
$36-43$ & 77 & 16,5 & Vocational School & 77 & 17,2 \\
$44-21$ & 52 & 11,2 & Graduate & 138 & 30,8 \\
$52-$ & 30 & 6,4 & Post Graduate or & 126 & 28,1 \\
& & & Doctorate & 448 & 100,0 \\
Total & 466 & 100,0 & Total & Frequency & Percent \\
Gender & Frequency & Percent & Income & 83 & 18,6 \\
Female & 212 & 49,4 & 500 and below & 147 & 32,9 \\
Male & 217 & 50,6 & $501-1500$ & 110 & 24,6 \\
Total & 429 & 100 & $1501-2500$ & 91 & 20,4 \\
Marital status & Frequency & Percent & $2501-5000$ & 16 & 3,6 \\
Single & 212 & 44.8 & 5001 and above & 447 & 100,0 \\
Married & 260 & 55,2 & Total & & \\
Total & 472 & 100 & & & \\
\hline
\end{tabular}

There are 212 female and 217 male participants in the study. The largest group is $18-25$ age group with the number of 195 participants in the classification of consumers according to age groups. While the number is 212 for the marrieds, it is 260 for the singles. It is seen that the graduate degree comes in the first place with 183 people according to the education level of consumers. 500 - 1500 Turkish Lira of income seems to be in the first group with a number 147 according to the income level of consumers. According to the results obtained from the descriptive analysis of the survey demographic characteristics of the consumers are given in Tab. 1.

Table 2. Reliability Statistics

\begin{tabular}{cc}
\hline Cronbach's Alpha & N of Items \\
\hline, 909 & 38 \\
\hline
\end{tabular}

In the Tab. 2, reliability test results were given. Reliability test results of the attitude scale (Cronbach's Alpha) value is (0.909) and it is quite high.

Table 3. KMO and Bartlett's Test

\begin{tabular}{llr}
\hline Kaiser-Meyer-Olkin Measure of Sampling Adequacy. &, 869 \\
\hline Bartlett's Test of Sphericity & Approx. Chi-Square & 5736,533 \\
& df & 378 \\
& Sig. &, 000 \\
\hline
\end{tabular}

In the Tab. 3, KMO and Bartlett's Test results were given. Kaiser-Meyer-Olkin Measure of Sampling adequacy value reports the amount of variance created by the shared variables. If this value is close to 1.00 , then it is accepted that the data is suitable for factor analysis. As can be seen in the table, $\mathrm{KMO}$ value is 0.869 and the used data is appropriate for 
the factor analysis.

Table 4. The results of the factor analysis related items regarding Perceptions, Attitudes and Expectations of the consumers about Halal Products

\begin{tabular}{|c|c|c|c|}
\hline Items & $\begin{array}{l}\text { Factor } \\
\text { Loadings }\end{array}$ & $\begin{array}{l}\text { of } \\
\text { Variance }\end{array}$ & $\begin{array}{l}\text { Cronbach } \\
\text { Alpha }\end{array}$ \\
\hline Factor 1 - PROMOTION & & 11,554 & ,895 \\
\hline 1 I buy the halal products through newspaper advertisements & 859 & & \\
\hline 2 I buy the halal products through the radio and internet advertisements & ,913 & & \\
\hline 3 I buy the halal products through brochures and banners & 840 & & \\
\hline 4 I buy the halal products through TV advertisements &, 787 & & \\
\hline Factor 2 - PLACE & & 10,172 & ,799 \\
\hline 8 I always buy the halal products at the restaurants I go shopping & ,714 & & \\
\hline 9 I buy the halal products at the groceries &, 720 & & \\
\hline 10 I buy the halal products at the markets & 852 & & \\
\hline 11 I buy the halal products at hyper markets &, 757 & & \\
\hline Factor 3 - ATTRACTIVE AND QUALITY & & 7,461 &, 710 \\
\hline 12 Halal products in the market are in good quality &, 775 & & \\
\hline $\begin{array}{l}13 \text { The features of halal products in the market are according to consumer taste and } \\
\text { requirement }\end{array}$ &, 812 & & \\
\hline 14 Halal products in the market have attractive design &, 597 & & \\
\hline Factor 4 - HALAL CERTIFICATION & & 13,051 & ,782 \\
\hline 17 Halal products in the market includes all types of consumers products & 753 & & \\
\hline 18 Halal certified products should be monitored from competent authorities &, 807 & & \\
\hline $\begin{array}{l}19 \text { Manufacturers which deceive on its halal certificates should be penalized } \\
\text { accordingly }\end{array}$ & ,802 & & \\
\hline 20 It is important to have warranty on halal products &, 580 & & \\
\hline 21 Halal certified products are suitable for global market &, 597 & & \\
\hline 22 Halal products manufactured in Turkey should get halal certification & 639 & & \\
\hline Factor 5 - PRICE & & 8,544 &, 719 \\
\hline 27 Price has been the main determinant when purchasing halal products & ,788 & & \\
\hline 28 I buy the halal products if it has a free gift &, 760 & & \\
\hline 29 I buy the halal products at discount &, 717 & & \\
\hline 36 Halal products are for Muslim consumers only &, 585 & & \\
\hline Factor 6 -MARKET DEMAND & & 11,492 &, 816 \\
\hline 30 Demand for halal products determines price of halal products & 664 & & \\
\hline 31 Halal products with extra services can be more attractive &, 747 & & \\
\hline 32 Halal food products are cheaper if sold at hypermarkets &, 723 & & \\
\hline 33 Products manufactured by SMEs can generally be cheaper & 654 & & \\
\hline $\begin{array}{l}34 \text { SMEs halal food product manufacturers are more willing to give consumer } \\
\text { discount when compared to the large companies }\end{array}$ &, 519 & & \\
\hline Total Varience & & 62,272 & \\
\hline
\end{tabular}

In the Tab. 4, the items were subjected to the factor analysis and the results of factor analysis were given. According to the results of the factor analysis, 6 factor sizes emerged. Factors sizes were given below. From this analysis, we can say that there are 6 factors which may influence the consumers to buy Halal products. 
1. Factor: PROMOTION

2. Factor: PLACE

3. Factor: ATTRACTIVENESS AND QUALITY

4. Factor: HALAL CERTIFICATION

5. Factor: PRICE

6. Factor: MARKET DEMAND

Table 5. Mean and One-sample T-test Results of Attitudes of Consumers towards Halal Products

\begin{tabular}{lccrrrr}
\hline & $\mathrm{N}$ & Mean & Std. Deviation & \multicolumn{1}{c}{$\mathrm{t}$} & $\mathrm{df}$ & Sig. (2-tailed) \\
\hline PROMOTION & 463 & 2,3688 & 1,05153 & $-12,916$ & 462 &, 000 \\
PLACE & 451 & 3,0771 & 1,04816 & 1,561 & 450 &, 119 \\
ATTRACTIVENESS AND QUALITY & 452 & 2,9299 &, 98861 & $-1,507$ & 451 &, 133 \\
HALAL CERTIFICATION & 444 & 4,3352 & 1,01842 & 27,626 & 443 &, 000 \\
PRICE & 452 & 2,6244 & 1,00422 & $-7,951$ & 451 &, 000 \\
MARKET DEMAND & 451 & 3,3663 &, 95820 & 8,118 & 450 &, 000 \\
\hline
\end{tabular}

In the Tab. 5, mean and one-sample t-test results of attitudes of consumers towards halal products were given. The mean size of the determinants of consumers' attitudes towards halal products and one sample $t$ test results were given above. Considering the mean values, and t-test results, while consumers have negative views on the factor 1 (promotion) and factor 5 (price), they have positive opinions concerning factor 4 (halal certification) and factor 6 (market demand). However, consumers are unstable-undecided- for factor 2 (place) and factor 3 (attractive and quality).

Table 6. T-test Results of Consumers' Attitudes towards Halal Products by Gender

\begin{tabular}{|c|c|c|c|c|c|c|c|}
\hline FACTORS & Gender & $\mathrm{N}$ & Mean & $\begin{array}{c}\text { Std. } \\
\text { Deviation }\end{array}$ & $\mathrm{t}$ & $\mathrm{df}$ & Sig. (2-tailed) \\
\hline \multirow[t]{2}{*}{ PROMOTION } & Male & 209 & 2,3541 & 1,03902 &,- 349 & 421 & ,727 \\
\hline & Female & 214 & 2,3902 & 1,08564 & & & \\
\hline \multirow{2}{*}{ PLACE } & Male & 202 & 3,1324 & 1,02037 & 1,176 & 410 & 240 \\
\hline & Female & 210 & 3,0107 & 1,07725 & & & \\
\hline \multirow{2}{*}{$\begin{array}{l}\text { ATTRACTIVENESS AND } \\
\text { QUALITY }\end{array}$} & Male & 205 & 2,9675 & 1,00436 &, 759 & 415 & ,448 \\
\hline & Female & 212 & 2,8931 & 99609 & & & \\
\hline \multirow{2}{*}{ HALAL CERTIFICATION } & Male & 202 & 4,4150 & 1,05045 & 1,641 & 406 & , 102 \\
\hline & Female & 206 & 4,2460 & 1,03065 & & & \\
\hline \multirow[t]{2}{*}{ PRICE } & Male & 204 & 2,6887 & 1,01524 & ,961 & 411 &, 337 \\
\hline & Female & 209 & 2,5921 & 1,02795 & & & \\
\hline \multirow[t]{2}{*}{ MARKET DEMAND } & Male & 204 & 3,4069 & ,91928 & 1,093 & 412 & 275 \\
\hline & Female & 210 & 3,3029 & 1,01326 & & & \\
\hline
\end{tabular}

In the Tab. 6, t-test results of consumers' attitudes towards halal products by gender were given. According to the data, there are no differences among all the factor groups according to the gender.

Table 7. Anova Test Results of the Consumers' Attitudes Regarding Halal Products According to Their Incomes

\begin{tabular}{lrr}
\hline FACTORS & Anova F Value & P Value \\
\hline PROMOTION & 2,225 &, 066 \\
PLACE & 1,446 &, 218 \\
ATTRACTIVENESS AND QUALITY & 1,433 &, 222 \\
HALAL CERTIFICATION & 1,480 &, 207 \\
PRICE & 1,666 &, 157 \\
MARKET DEMAND & 1,257 &, 286 \\
\hline
\end{tabular}

In the Tab. 7, anova test results of the consumers' attitudes regarding halal products according to their incomes were given. This analysis was conducted to test whether the attitudes of the consumers differ towards halal certified products according to their incomes. All factor sizes showed no differences. 
Table 8. Anova Test Results of the Consumers' Attitudes Regarding Halal Products According to Their Ages

\begin{tabular}{lcc}
\hline FACTORS & Anova F Value & P Value \\
\hline PROMOTION &, 939 &, 441 \\
PLACE &, 220 &, 927 \\
ATTRACTIVENESS AND QUALITY &, 771 &, 544 \\
HALAL CERTIFICATION & 3,781 &, 005 \\
PRICE &, 392 &, 814 \\
MARKET DEMAND & 1,459 &, 214 \\
\hline
\end{tabular}

In the Tab. 8, anova test results of the consumers' attitudes regarding halal products according to their ages were given. This anaylsis was performed to test whether the attitudes of the consumers' differ towards halal certified products according to their ages. Differences of opinion emerged only in halal certification according to consumers' ages. There were differences in the opinion in factor 4 (halal certification) among young and middle-aged consumers. In the other factor groups, no differences appeared.

Table 9. Anova Test Results of the Consumers' Attitudes Regarding Halal Products According to Their Education Levels

\begin{tabular}{lcc}
\hline FACTORS & Anova F Value & P Value \\
\hline PROMOTION & 4,455 &, 002 \\
PLACE & 4,496 &, 001 \\
ATTRACTIVENESS AND QUALITY &, 940 &, 441 \\
HALAL CERTIFICATION & 5,012 &, 001 \\
PRICE & 4,014 &, 003 \\
MARKET DEMAND & 2,039 &, 088 \\
\hline
\end{tabular}

In the Tab. 9, anova test results of the consumers' attitudes regarding halal products according to their education levels were given. This analysis was done to test whether the attitudes of the consumers' differ towards halal certified products according to their education levels. According to the analysis, there appeared differences in the opinion regarding promotion, place, and halal certificate and price sizes. Differences in the opinion were observed between those whose education level were the lowest and the highest. There were no differences in the opinion concerning attractiveness and quality and market demand.

Table 10. T-test Results of Consumers' Attitudes towards Halal Products by Their Marital Status

\begin{tabular}{lrccrccr}
\hline \multicolumn{1}{c}{ FACTORS } & Marital Status & $\mathrm{N}$ & Mean & Std. Deviation & $\mathrm{t}$ & $\mathrm{df}$ & Sig. (2-tailed) \\
\hline PROMOTION & Married & 250 & 2,4220 & 1,06322 & 1,136 & 457 &, 256 \\
& Single & 209 & 2,3098 & 1,04122 & & & \\
PLACE & Married & 245 & 3,1296 & 1,05717 & 1,142 & 445 &, 254 \\
\multirow{2}{*}{ ATTRACTIVENESS AND QUALITY } & Single & 202 & 3,0161 & 1,03155 & & & \\
& Married & 241 & 2,8755 & 1,03378 & $-1,297$ & 446 &, 195 \\
\multirow{2}{*}{ HALAL CERTIFICATION } & Single & 207 & 2,9968 &, 92897 & & & \\
& Married & 238 & 4,3606 & 1,13570 &, 449 & 438 &, 653 \\
PRICE & Single & 202 & 4,3168 &, 86147 & & & \\
& Married & 245 & 2,6082 & 1,05024 &,- 248 & 446 &, 804 \\
MARKET DEMAND & Single & 203 & 2,6318 &, 94211 & & & \multirow{2}{*}{, 996} \\
& Married & 245 & 3,3649 &, 99420 &,- 005 & 445 & \\
\hline & Single & 202 & 3,3653 &, 92429 & & & \\
& & & & & & &
\end{tabular}

In the Tab. 10, t-test results of consumers' attitudes towards halal products by their marital status were given. According to the data, there are no differences among all the factor groups according to their marital status. 
Table 11. Mean and One-Sample t-test results towards consumers' reasons for halal consumption

\begin{tabular}{lccrrrr}
\hline ITEMS & $\mathrm{N}$ & Mean & Std. Deviation & $\mathrm{t}$ & df & Sig. (2-tailed) \\
\hline I consume halal products because I'm Muslim & 472 & 4,4958 & 1,01160 & 32,124 & 471 &, 000 \\
I consume halal products because I think it is ethically appropriate & 465 & 3,9484 & 1,34930 & 15,157 & 464 &, 000 \\
I consume halal products because I think they are better quality & 470 & 3,8064 & 1,29735 & 13,475 & 469 &, 000 \\
I consume halal products because they are cheaper & 466 & 2,1052 & 1,27999 & $-15,092$ & 465 &, 000 \\
I consume halal products because they can easily be found & 466 & 2,3112 & 1,35827 & $-10,948$ & 465 &, 000 \\
\hline
\end{tabular}

In the study, that the reasons for consumers' consumption of halal products and their opinions about products with halal logo were also tried to be determined. The results were shown in the Tab. 11.

The mean and one sample $t$ test values about the reasons for the consumption of halal products of consumers were given above. Considering mean values, the item "I consume halal products because I'm Muslim" is the most accepted item in Turkey among the consumers. It is therefore be concluded that for the consumers in Turkey, religion is quite significant and they thus pay attention for the products they consume. In other words, being a Muslim means consuming halal products and so Muslim consumers in Turkey should purchase halal products as requested by their religion when they go on shopping. Besides, the item "I consume halal products because I think it is ethically appropriate" and the item "I consume halal products because I think they are better quality" are also accepted items by the consumers. Therefore, it can be inferred that consumers in Turkey buy halal products, for the halal product is also ethically suitable and better quality for the consumption in addition to being accepted as suitable for the Muslim consumers. However, the items "I consume halal products because they are cheaper" and "I consume halal products because they can easily be found" are not as much accepted as the item mentioned above, that's, they are not regarded as much important concerning the consumption reason.

Table 12. Mean and One-Sample T-test Results towards Consumers' Evaluations for Halal Consumption

\begin{tabular}{|c|c|c|c|}
\hline ITEMS & $\mathrm{N}$ & Mean & Std. Deviation \\
\hline I check the Halal Logo of the product I buy & 472 & 3,5869 & 1,33898 \\
\hline I buy products with Halal Logo & 470 & 3,7170 & 1,28079 \\
\hline Halal Logo is very important to me and I trust this logo & 471 & 3,7155 & 1,25128 \\
\hline I ask the seller whether the product is halal if it does not have "Halal Logo" & 470 & 3,1128 & 1,38144 \\
\hline Halal Logo is an instrument that is used purely for marketing & 469 & 2,9211 & 1,32858 \\
\hline The Halal Logo has lost its influence on secular societies & 457 & 2,8403 & 1,96869 \\
\hline I leave the responsibility to the seller if the product I buy has Halal Logo & 464 & 3,6983 & 1,24508 \\
\hline Products with Halal Logo conform to Islamic requirements & 468 & 3,8996 & 1,12236 \\
\hline All of the products, notably food must have Halal Logo & 471 & 4,1911 & 1,13062 \\
\hline Substances in food and beverages are important for Muslim consumers. & 468 & 4,5235 & ,94466 \\
\hline The preservatives used in halal products may be accepted by consumers & 469 & 3,3902 & 1,28235 \\
\hline Production phase of the product is very important in determining whether the product is lawful & 473 & 4,4228 & 94042 \\
\hline
\end{tabular}

In the Tab. 12, mean and one-sample t-test results towards consumers' evaluations for halal consumption were given. Consumers have abstained, that's noncommittal, opinions on the products with halal logo in the items which are "I ask the seller whether the product is halal if it does not have Halal Logo", "Halal Logo is an instrument that is used purely for marketing" and "The Halal Logo has lost its influence on secular societies" respectively. However, consumers are involved in all other expressions.

\subsection{Discussions and Policy Recommendations}

In this study, what the perceptions, attitudes and expectations of the consumers towards halal certified products are and whether these perceptions, attitudes and expectations differ according to consumers' demographic characteristics were investigated. According to the obtained reliability test results, the attitude scale (Cronbach's Alpha) value is (0.909) and it is quite high. Besides, Kaiser-Meyer-Olkin Measure of Sampling adequacy value reports the amount of variance created by the shared variables. As can be understood from KMO value, which is 0.869 in this study, the used data is 
appropriate for the factor analysis. According to the factor analysis, there appeared six factor sizes in this study, which is fewer when compared with the one conducted in Malaysia by Dali and et al. (2008). A number of reasons can be given for this. First, this study was conducted in Isparta, Turkey and so it is quite usual that there can appear some different opinions regarding the halal food and halal certification. Second, it can also be stated that there has not been enough awareness concerning halal food and halal certification in Isparta. Third and maybe the most striking one, if a food is considered halal, then it is already clean, its sample is already tried which are factors that emerged in the study conducted by Dali and et al. 2008. It is thus normal that all other 5 factors did not emerge in this study.

According to the tested hypothesis of this study "Consumers' perception of halal products, attitudes and expectations differ according to their demographic characteristics", there appeared no differences concerning the consumers' marital statuses, genders and incomes. It is hence can be said that for those socio-demographic characteristics the hypothesis was rejected. However, there appeared some differences of opinion about the halal certificate among middle-aged and young people. Furthermore, it is education level which creates significant differences in the socio-demographic characteristics. There appeared differences of opinion in all factors other than factor 3 (attractiveness and quality) among those whose education levels are low and high.

This study also tried to determine why consumers use halal products in Turkey. Religious belief ranks the first among those reasons. Furthermore, the belief that halal products are ethically appropriate and better quality is also another important consumption reason for consumers.

Consumers generally have positive opinions regarding products with halal logo. In this study, there appeared a preference and a prominent tendency to request products labeled halal logo among consumers. This shows it is important for the businesses to use the halal logo on the products they sell.

Halal sector in Turkey is growing each passing day in line with the growing demands of consumers which is enough for the businesses to pay attention to this humble new blue ocean market. In recent times, the ads made in this regard and the number of news regarding this topic show how important this blue ocean can be for the businesses in the near future. One way to be successful for the businesses running or will be operating in this sector in the future is that they shall comply with the wishes and needs of consumers. In this regard, it is important to learn the perceptions, attitudes and expectations of consumers' towards halal products, for the halal certification may provide the businesses with benefits in order to have a say and therefore to get more profit which is the most striking aim of the businesses.

This study is believed to guide both general public and businesses regarding this blue ocean market in which halal certificate or halal logo could be vitally important. This study is also regarded to be helpful for the further academic studies.

\section{References}

Al-Quran, C., A. (1993). Dört Mezhebe Göre İslam Fıkhı, Çağrı Yayınları, İstanbul.

Ameur, A. A. (2011). The Lifestyle Halal in European Marketing, Review of Economics \& Finance-Academic Research Centre of Canada, 83-90.

Batu, A. (2012) Türkiye'de Helal (Mahzursuz) Gıda ve Helal Belgelendirme Sistemi, Glda Teknolojileri Elektronik Dergisi, 7(1), 51-61.

Bergeud-Blackler, F., \& Bonne, K. (2005). Halal Food Concumption in France-Preliminary Results of A Study on Halal Food Consumption, AoFood.

Çakır, S. (2013). Yedikleriniz Helal Olsun, Işık Yayınları, İzmir.

Çayıroğlu, Y. (2014) Helal Gıda: İslam Hukuku’na Göre Helal Gıda, Işık Yayınları, İzmir.

Dali, N. R. S. B. M., Nooh M. N. B., Nawai N. B., \& Mohammad H. B.(2008). Is Halal Products Are More Expensive As Perceived By The Consumers? Muslimprenuers Challenges And Opportunities In Establishing A Blue Ocean Playing Field, Proceedings of International Conference on Entreprenuership: Towards Developing Entreprenuership Society, 27-28 May at Meritus Pelangi Beach Resort \& Spa Langkawi.

Golnaz, R., Zainalabidin, M., Mad, N. S., \& Eddie, C. F. C. (2009). Concerns for Halalness of Halal-Labelled Products among Muslim Consumers in Malaysia: Evaluation of Selected Demographic Factors, Economic and Technology Management Review, 4, 65-73.

Golnaz, R., Zainalabidin, M., Nasir, M. S., \& Eddie, C. F. C. (2010). Non-Muslims' Awareness of Halal Principles and Related Food Products in Malaysia, International Food Research Journal, 17, 667-674, 2010.

Golnaz, R., Zainalabidinm, M., Nasir, M. S. (2012). Assesment of Consumers' Confidence on Halal Labelled Manufactured Food in Malaysia, Pertanika J Soc. Sci and Hum, 20(1), 33-42. 
Gündüz, M. Ö. (2013) TS OIC / SMIIC 1 Helal Gıda Genel Kılavuzunun Uygulanması, Uluslararası 2. Helal ve Sağllklı Glda Kongresi, 7-10, 396-399.

Hussnain, S. A. (2011). What is Islamic Marketing? Global Journal of Management and Business Research, 11(11), 101-103.

Küçüköner, E. (2011) Helal Gıda Sertifikasyonunda Gıda Katkı Maddelerinin Yeri, 1. Ulusal Helal ve Sağglklı Gıda Kongresi, Glda Katkı Maddeler: Sorunlar ve Çözüm Önerileri, 19/20 Kasım 2011, Ankara, 12-17.

Kurtoğlu, R., \& Çiçek, B. (2013). Tüketicilerin Helal Ürünler Hakkındaki Algılama, Tutum ve Beklentilerini Tespit Etmeye Yönelik Bir araştırma, Eskişehir Osmangazi Üniversitesi İ̈BF Dergisi, Aralık, 8(3), 181-205.

Özdemir, H., \&Yaylı, A. (2014) Tüketicilerin Helal Sertifikalı Ürün Tercihleri Üzerine Bir Araştırma İstanbul İli Örneği, İşletme Araştırmaları Dergisi, 183-202.

Sabah Gazetesi-Ekonomi, "Rüşvetle Helal Sertifikası" 9 Aralık 2011 http://www.sabah.com.tr/ekonomi/2011/12/09/rusvetle-helal-sertifikasi (Access date: 03.01.2015).

Shahidan, S., \& Othman, M. N. (2006). Halal Certification: An International Marketing Issues and Challenge, Proceeding at the International IFSAM VIIIth World Congress, 1-11.

Soesilowati, E. S. (2010). Business Opportunities for Halal Products in the Global Market: Muslim Consumer Behaviour and Halal Food Consumption, Journal of Indonesian Social Sciences and Humanities, 3, 151-160.

Swimberghe, K., Dheeraj, S., \& Flurry, L. (2009). An Exploratory Investigation of the Consumer Religious Commitment and Its Influence on Store Loyalty and Consumer Complaint Intentions, Journal of Consumer Marketing, 340-347.

Teng, K. P. (2013). Awareness, Recognition and Intention: Insights From A Non-Muslim Consumer Survey Regarding Halal Labelled Food Products in Malaysia, 3rd International Conference on Management, 10-11 June 2013, Penang, Malaysia. http://www.etikadanismanlik.com/fky24.htm-5846 Sayılı Fikir ve Sanat Eserleri Kanunu (Access date: 04.11.2014).

Torlak, Ö. (2010). İslam Ülkerleri Arasında Helal Ürün Pazarlama Potansiyeli, Problemleri ve Çözüm Önerileri, Tüketici ve Tüketici Araştırmaları Dergisi, 4(2), 1-9.

Yurttagül, M., \& Ayaz, A. (2008). Katkı Maddeleri: Yanlışlar ve Doğrular, Ankara, 8.

Zakaria, Z. (2008). Tapping into the World Halal Market: Some Discussions on Malaysian Laws and Standarts, Shariah Journal, 16, Special Edition, 603-616.

\section{(cc) $\mathrm{Br}$}

This work is licensed under a Creative Commons Attribution 3.0 License. 